アミロイド $\beta$ ペプチドの凝集・毒性発現の分子メカニズムの解明と 低分子化合物による阻害：アルツハイマー病の克服に向けて

\author{
山國徹
}

\title{
Elucidation of Mechanism Underlying Amyloid- $\beta$ Peptide Aggregation and Its Neurotoxicity Expression and Inhibition of These Molecular Processes by Beneficial Synthetic and Natural Compounds with Low-molecular Weights - New Approaches to Fundamental Treatment and Prevention of Alzheimer's Disease-
}

Tohru YAMAKUNI

Graduate School of Pharmaceutical Sciences, Tohoku University, 6-3 Aoba, Aramaki, Aoba-ku, Sendai 980-8578, Japan

厚生労働省が最近報告した認知症高齢者の人口に 関するデータによれば，2035 年にはわが国の認知 症高齢者の人口は 445 万人に達する見込みである. この推計データは, 未曾有の超高齢化社会を迎えた わが国において，認知症の羅患率が予想をはるかに 上回るスピードで増加の一途をたどっていることを 示すものである。このような状況から，わが国にお けるアルツハイマー病（AD）等の認知症の克服は 焦眉の国家的課題であり，その予防法及び原因療法 の確立が待望されている. 認知症の中で最も発症率 の高い疾患が $\mathrm{AD}$ である。しかし， $\mathrm{AD}$ の最初の症 例報告（1907）から既に一世紀が経過した現在，い まだその根本治療薬は開発されていない.

$\mathrm{AD}$ は認知機能障害と記憶力の低下を伴う進行性 中枢神経変性疾患であり，その原因として脳内での 原因物質アミロイド $\beta$ ペプチド $(\mathrm{A} \beta)$ の重合・凝 集が考えられている。 したがって，ADの発症メカ ニズムの中心には $\mathrm{A} \beta$ の重合・凝集とその結果誘発 される神経毒性発現があると理解できる. A $\beta$ は前 駆体タンパク質 (amyloid precursor protein, APP) から $\beta$ 及び $\gamma$ セクレターゼによる二段階切断によ り生成される，現在，世界のメガファーマではこの ような $\mathrm{A} \beta$ の生成過程を創薬のターゲットとし, $\mathrm{A} \beta$ の生成酵素の阻害によってその生成を抑制する

東北大学大学院薬学研究科薬物療法学 ( 仙台市青葉区荒巻字青葉 6-3)

e-mail: yamakuni@mail.pharm.tohoku.ac.jp 日本薬学会第 129 年会シンポジウムS22 序文
薬物, つまり $\beta$ 及び $\gamma$ セクレターゼ阻害薬を $\mathrm{AD}$ の原因療法薬として開発する研究が進められてい る.しかし，これまでに APP 以外にもセクレター ゼの内因性基質となる機能分子が相ついで発見さ れ，またセクレターゼ遺伝子のノックアウトマウス の機能異常の解析から， $\beta$ 及び $\gamma$ セクレターゼの阻 害薬の副作用のリスクの可能性が指摘されている.

したがって，セクレターゼ阻害薬を $\mathrm{AD}$ の原因療 法薬とする場合，副作用を回避するためにはその APP に対する高い選択性が必須である.

それでは $\mathrm{AD}$ の原因療法薬開発のための新たな 創薬のターゲットは何にすべきか. 今回の「アミロ イド $\beta$ ペプチドの凝集・毒性発現の分子メカニズ ムの解明と低分子化合物による阻害 : アルツハイ マー病の克服に向けて」のシンポジウムでは, $\mathrm{A} \beta$ の生成過程ではなく, その下流の $\mathrm{AD}$ 発症に係わ る $\mathrm{A} \beta$ のオリゴマー形成・凝集と神経毒性発現の過 程をターゲットにした創薬の可能性を探る. そこで, $\mathrm{A} \beta$ のオリゴマー形成・凝集の分子メカニズム, $\mathrm{A} \beta$ のオリゴマー形成・凝集による神経毒性発現の分子 メカニズムの研究，さらにはこのような分子過程を ターゲットにした創薬研究の分野で，わが国におい て優れた研究成果を挙げている 5 人の著者に最先端 の知見を紹介して頂き，新たな $\mathrm{AD}$ の予防・治療 薬の開発の可能性を考察したい. まず最初に, 本シ ンポジウムのオーガナイザーの一人である三浦隆史 氏（東北大学大学院）に $\mathrm{A} \beta$ 凝集の原因となる可能 性が指摘されている生体成分の $\mathrm{A} \beta$ のコンホメーシ 
ヨンに対する影響について発表して頂く，第二番目 には, 内木宏延氏（福井大学医学部）にアミロイド 線維形成機構を説明するモデルとして注目されてい る重合核（オリゴマー）依存性重合モデルを解説し て頂き，さらに線維形成阻害薬の探索研究から発見 された抗アミロイド化合物の nordihydroguaiaretic acid とワイン関連ポリフェノールなどの抗アミロ イド効果のメカニズムについて紹介して頂く. 第三 番目には，ガングリオシドクラスターを介して神経 毒性を持つ $\mathrm{A} \beta$ アミロイドの形成が起こるとの独自 の理論を提唱している松崎勝巳氏(京都大学大学院) に脂質ラフトを介した $\mathrm{A} \beta$ の凝集メカニズムと低分 子化合物による脂質ラフトにおけるアミロイド形成 阻害について解説を頂く，第四番目の筆者は，天然
界に $\mathrm{AD}$ 原因療法薬を求める探索研究を進め, 発 見した漢方薬陳皮の抗認知症成分ノビレチン (nobiletin) の $\mathrm{A} \beta$ の神経毒性発現抑制作用及び APP Tg マウスにおける $\mathrm{A} \beta$ 誘発性記憶障害改善作 用について述べる。最後の五番目では，国内では唯 一の $\mathrm{AD}$ 治療薬であるアリセプトの開発者である 杉本八郎氏（京都大学大学院）が，「ベータアミロ イド仮説に基づくアルツハイマー病治療薬の研究開 発」の最近の動向について概説頂き，併せて天然物 を素材とした彼らの最近の創薬アプローチについて 述べられる.

今回の誌上シンポジウムが安全性の高い $\mathrm{AD} の$ 原因療法薬の開発研究の先導役となれば幸いである. 